Original Article

\title{
Studies on parasitic prevalence in pet birds from Punjab, Pakistan
}

\author{
Estudos de prevalência parasítica em pássaros de estimação de Punjab, Paquistão
}

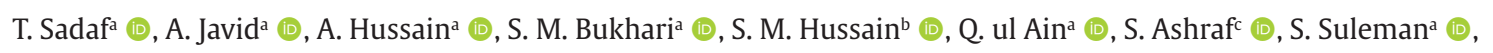

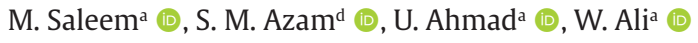

aniversity of Veterinary and Animal Sciences, Department of Wildlife and Ecology, Lahore, Pakistan

${ }^{\mathrm{b} G o v e r n m e n t ~ C o l l e g e ~ U n i v e r s i t y, ~ D e p a r t m e n t ~ o f ~ Z o o l o g y, ~ F a i s a l a b a d, ~ P a k i s t a n ~}$

'The University of Lahore, Department of Zoology, Sargodha Campus, Sargodha, Pakistan

d University of Education Lahore, Department of Zoology, Lahore, Pakistan

\begin{abstract}
During this one year study, blood and fecal samples of doves (Zenaida asiatica), ducks (Anas platyrhynchos), pigeons (Columba livia), partridges (Alectoris chukar), turkeys (Meleagris gallopavo) and goose (Chen caerulescens) were collected to assess the parasitic prevalence in these birds. The birds were kept at Avian Conservation and Research Center, Department of Wildlife and Ecology, University of Veterinary and Animal Sciences, Lahore. All these avian species were kept in separate cages and their entire body was inspected on regularly basis to record external parasites. For internal parasites, 100 blood and 100 fecal samples for each species were analyzed. During present study, two species of ectoparasites i.e. fowl ticks (Args persicus) and mite (Dermanyssus gallinae) while 17 species of endoparasites; three from blood and 14 from fecal samples were identified. Prevalence of blood parasites was Plasmodium juxtanucleare 29.3\%, Aegyptinella pullorum 15\% and Leucoctoyzoon simond 13\%. Parasitic species recorded from fecal samples included 6 species of nematodes viz. Syngamus trachea with parasitic prevalence of $50 \%$, Capillaria anatis $40 \%$, Capillaria annulata $37.5 \%$, Heterakis gallinarum $28.3 \%$, Ascardia galli $24 \%$ and Allodpa suctoria $2 \%$. Similarly, two species of trematodes viz. Prosthogonimus ovatus having parasitic prevalence of $12.1 \%$ and Prosthogonimus macrorchis 9.1\% were also recorded from fecal samples of the birds. Single cestode species Raillietina echinobothrida having parasitic prevalence of $27 \%$ and 3 protozoan species i.e. Eimeria maxima having prevalence $20.1 \%$, Histomonas meleagridis $8 \%$ and Giardia lamblia $5.3 \%$ were recorded. In our recommendation, proper medication and sanitation of the bird's houses and cages is recommended to avoid parasites.
\end{abstract}

Keywords: Plasmodium, blood parasites, domestic birds, Haemoproteus, Leucocytozoon.

\begin{abstract}
Resumo
Durante este estudo de um ano, amostras de sangue e fezes de pombos (Zenaida asiatica), patos (Anas platyrhynchos), pombos (Columba livia), perdizes (Alectoris chukar), perus (Meleagris gallopavo) e ganso (Chen caerulescens) foram coletados para avaliar a prevalência de parasitas nessas aves. As aves foram mantidas no Centro de Conservação e Pesquisa de Aves, Departamento de Vida Selvagem e Ecologia, Universidade de Veterinária e Ciências Animais, Lahore. Todas essas espécies de aves foram mantidas em gaiolas separadas e todo o seu corpo foi inspecionado regularmente para registrar parasitas externos. Para parasitas internos, foram analisadas 100 amostras de sangue e 100 amostras fecais de cada espécie. Durante o presente estudo, duas espécies de ectoparasitas, ou seja, carrapatos de aves (Args persicus) e ácaros (Dermanyssus gallinae), enquanto 17 espécies de endoparasitas, três de sangue e 14 de amostras fecais, foram identificadas. Os parasitas sanguíneos prevalentes foram Plasmodium juxtanucleare, 29,3\%, Aegyptinella pullorum, 15\%, e Leucoctoyzoon simond, 13\%. As espécies parasitas registradas em amostras fecais incluíram 6 espécies de nematoides viz. Syngamus traqueia com prevalência parasitária de 50\%, Capillaria anatis, 40\%, Capillaria annulata, 37,5\%, Heterakis gallinarum, 28,3\%, Ascardia galli, 24\% e Allodpa suctoria, 2\%. Da mesma forma, duas espécies de trematódeos viz. Prosthogonimus ovatus com prevalência parasitária de 12,1\% e Prosthogonimus macrorchis, 9,1\%, também foram registrados nas amostras fecais das aves. Espécies de cestoide único Raillietina echinobothrida com prevalência parasitária de $27 \%$ e 3 espécies de protozoários, ou seja, Eimeria maxima tendo prevalência de 20,1\%, Histomonas meleagridis, $8 \%$, e Giardia lamblia, 5,3\%, foram registradas. Em nossa recomendação, são indicados medicação adequada e saneamento das casas e gaiolas dos pássaros para evitar parasitas.
\end{abstract}

Palavras-chave: Plasmodium, parasitas sanguíneos, aves domésticas, Haemoproteus, Leucocytozoon.

*e-mail: arshadjavid@uvas.edu.pk

Received: December 4, 2020 - Accepted: February 3, 2021

This is an Open Access article distributed under the terms of the Creative Commons Attribution License, which permits unrestricted use, distribution, and reproduction in any medium, provided the original work is properly cited. 


\section{Introduction}

Commercial farmers prefer confined facilities for birds as density of the birds is higher and these facilities aid to boost their populations. However, higher densities of the birds result in transmission of parasitic agents (Krystianiak et al., 2007) and pathogenic microbes that hinder growth and egg production (Dranzoa et al., 1999). In birds, disease causing species like roundworms reduce breeding success and species like Syngamus trachea, Ascaridia spp, Heterakis isolonche, Capillaria spp. and Eimeria spp. cause coccidiosis (Goldova et al., 1993). Blood parasites viz. Plasmodium spp. and Leukocytozoon spp. are common in feral as well as domestic birds which result in higher mortalities (Aguirre et al., 1986).

In many countries, birds are reared on ground in aviaries where they remain in permanent contact with soil. The soil serves as reservoir for larval insects and helminthes. These factors clearly reflect the presence of wide range of parasites in birds kept in free-range rearing facilities and in turn result in low production (Permin et al., 1997). Amongst parasitic diseases, protozoan diseases especially coccidiosis is top of the list of parasites affecting birds worldwide and result in diarrhea, poor growth, and higher mortalities especially in young birds. Moreover, in confined facilities, birds are more susceptible to parasites and pathogenic microorganisms (Krystianiak et al., 2007).

Poor families keep many avian species as domestic poultry and use these birds as source of food and recreation. However, due to apparent less importance of these birds, little attention in terms of research has been dedicated towards these species and there is paucity of knowledge on health, socio-economic aspects, importance and management strategies of these birds. Understanding parasitic prevalence in poultry birds will aid in developing strategies to manage avian population (Sol and Lefebvre, 2000; Adriano and Cordeiro, 2001). Present study was therefore planned to study the parasitic prevalence in some captive avian species.

\section{Materials and Methods}

\subsection{Sampling}

Present one year study was conducted to check the parasitic prevalence in doves (Zenaida asiatica), ducks (Anas platyrhynchos), pigeons (Columba livia), partridges (Alectoris chukar), turkeys (Meleagris gallopavo) and goose (Chen caerulescens) was conducted at Avian Conservation and Research Center, Department of Wildlife and Ecology, C-Block, Ravi Campus, University of Veterinary and Animal Sciences, Lahore.

\subsection{Identification of ectoparasites}

To determine ectoparasites, the whole body of the birds was fully examined visually on weekly basis and the parasites were collected with the help of forceps and observed and identified under A.KRÜSS Optronic MSL4000-10/30-IL-TL stereo microscope.

\subsection{Fecal sampling and parasites identification}

Fresh fecal samples $(n=100)$ for each of the captive species were collected and brought to the laboratory for analysis through Smear method. Simple floatation and sedimentation techniques were used to detect parasitic oocytes or eggs. Later on, quantitative fecal sample examination, in term of oocysts per gram of feces was conducted using Macmaster's egg counting technique. The oocytes were repeatedly examined for micrometery. The species were identified through microscopic examination of oocysts and eggs (Atkinson CT et al. 2009).

\subsection{Blood sampling and parasites analysis}

Blood samples ( $n=100)$ from brachial vein of each of the avian species including were collected for endoparasites identification. A drop of fresh blood was placed on a clean glass slide and smear was prepared. Methyl alcohol was used for smear fixation and staining was carried out through Giemsa stain for 5 to 10 minutes. The stained slides were washed with distilled water, dried out and observed under light microscope. Taxonomic keys were used to precisely identify the parasitic species.

\section{Results and Discussion}

Temporal and spatial variations in parasitic prevalence are well documented and these variations are attributed with intermediate hosts (Cooper, 2005). Helminth species are highly diverse and are greatly distributed in Asia (Pandey et al. 1992; Bagust, 1994). During present study, a total of nine species of helminthes were recorded including six species of nematodes Syngamus trachea, Capillaria annulata, C. anatis, Ascardia galli, Heterakis gallinarum and Allodopa suctoria, two species of trematodes Prosthogonimus ovatus, P. macrorchis and one species of cestode Raillietina echinobothrida. Ascardia galli, Heterakis gallinarum, and Capillaria annulata (Table 1) are common parasitic species of commercial poultry (Permin et al. 1997). Important helminthic diseases of poultry are ascariodiosis and cestodiosis (Fatihu et al. 1991). One hundred helminth species have been identified from wild and domesticated avian species. Parasitic infections in poultry may result in reduction in growth and egg laying (Van Hemert et al., 2019). Nematodes have been recorded from poultry and other domestic avian species and their presence in birds results in serious infection of digestive tract (Gylstorff and Grimm, 1998).

During present study, Syngamous trachea was recorded from gut content of geese and turkeys and its prevalence was 50\%. Glystorff and Grimm (1998) reported Syngamus trachea is responsible for respiratory disorder in chicken, quail, gees peafowl, guinea fowl and turkey. During present study, Ascardia galli was recorded from fecal samples of ducks, dove, turkeys and geese and its prevalence was $24 \%$. Greiner (1997) reported that ascardial roundworm is present in different avian fauna. Most common helminth disease of poultry is Ascariodiosis (Fatihu et al. 1991). Prevalence of Cappillaria annulata was $37.5 \%$ while that 
Table 1. List of parasites identified in different avian species during study period.

\begin{tabular}{|c|c|c|c|c|c|c|c|c|c|c|}
\hline Parasites & Turkey & Pigeon & Duck & Dove & Partridge & Geese & Diagnosis & $\begin{array}{c}\text { Total } \\
\text { Samples } \\
\text { Collected }\end{array}$ & $\begin{array}{l}\text { Samples } \\
\text { positive } \\
\text { for } \\
\text { Parasite }\end{array}$ & $\begin{array}{c}\text { Percent } \\
\text { Prevalence }\end{array}$ \\
\hline \multicolumn{11}{|l|}{ Nematodes } \\
\hline $\begin{array}{l}\text { Syngamus } \\
\text { trachea }\end{array}$ & $\bullet$ & $\bullet$ & $\bullet \bullet$ & $\bullet \bullet$ & $\bullet \bullet$ & $\bullet$ & $\begin{array}{c}\text { Faecal smears } \\
\text { analysis }\end{array}$ & 600 & 300 & $50 \%$ \\
\hline $\begin{array}{l}\text { Capillaria } \\
\text { annulata }\end{array}$ & $\bullet$ & $\bullet$ & $\bullet \bullet$ & $\bullet \bullet$ & $\bullet$ & $\bullet$ & $\begin{array}{l}\text { Faecal smears } \\
\text { analysis }\end{array}$ & 600 & 225 & $37.5 \%$ \\
\hline Capillaria anatis & $\bullet$ & $\bullet$ & $\bullet$ & $\bullet$ & $\bullet \bullet$ & $\bullet$ & $\begin{array}{c}\text { Faecal smears } \\
\text { analysis }\end{array}$ & 600 & 240 & $40 \%$ \\
\hline Ascardia galli & - & $\bullet$ & $\bullet$ & - & $\bullet \bullet$ & $\bullet$ & $\begin{array}{c}\text { Faecal smears } \\
\text { analysis }\end{array}$ & 600 & 144 & $24 \%$ \\
\hline $\begin{array}{l}\text { Heterakis } \\
\text { gallinarum }\end{array}$ & $\bullet$ & $\bullet$ & $\bullet$ & $\bullet$ & $\bullet$ & $\bullet$ & $\begin{array}{l}\text { Faecal smears } \\
\text { analysis }\end{array}$ & 600 & 170 & $28.3 \%$ \\
\hline $\begin{array}{l}\text { Allodapa } \\
\text { suctoria }\end{array}$ & - & $\bullet$ & $\bullet$ & - & $\bullet$ & $\bullet$ & $\begin{array}{l}\text { Faecal smears } \\
\text { analysis }\end{array}$ & 600 & 12 & $2 \%$ \\
\hline \multicolumn{11}{|l|}{ Cestode } \\
\hline $\begin{array}{l}\text { Raillietina } \\
\text { echinobothrida }\end{array}$ & - & $\bullet$ & $\bullet \bullet$ & $\bullet \bullet$ & $\bullet \bullet$ & $\bullet$ & $\begin{array}{l}\text { Faecal smears } \\
\text { analysis }\end{array}$ & 600 & 162 & $27 \%$ \\
\hline \multicolumn{11}{|l|}{ Trmatode } \\
\hline $\begin{array}{l}\text { Prosthogonimus } \\
\text { ovatus }\end{array}$ & $\bullet \bullet$ & $\bullet$ & $\bullet$ & $\bullet \bullet$ & $\bullet \bullet$ & $\bullet$ & $\begin{array}{c}\text { Faecal smears } \\
\text { analysis blood, } \\
\text { analysis is also } \\
\text { performed }\end{array}$ & 600 & 73 & $12.1 \%$ \\
\hline $\begin{array}{l}\text { Prosthogonimus } \\
\text { macrorchis }\end{array}$ & $\bullet \bullet$ & $\bullet$ & $\bullet$ & - & $\bullet$ & $\bullet$ & $\begin{array}{c}\text { Faecal smears } \\
\text { analysis,blood } \\
\text { analysis also } \\
\text { performed }\end{array}$ & 600 & 55 & $9.1 \%$ \\
\hline \multicolumn{11}{|l|}{ Protozoa } \\
\hline Giardia lamblia & - & $\bullet$ & $\bullet \bullet$ & - & $\bullet \bullet$ & $\bullet$ & $\begin{array}{l}\text { Faecal analysis } \\
\text { or necroscopy }\end{array}$ & 600 & 32 & $5.3 \%$ \\
\hline Eimeria maxima & $\bullet$ & $\bullet \bullet$ & $\bullet$ & $\bullet \bullet$ & $\bullet \bullet$ & $\bullet$ & $\begin{array}{l}\text { Faecal analysis } \\
\text { or necroscopy }\end{array}$ & 600 & 121 & 20.1 \\
\hline $\begin{array}{l}\text { Histomonas } \\
\text { meleagridis }\end{array}$ & $\bullet$ & $\bullet$ & $\bullet \bullet$ & $\bullet \bullet$ & $\bullet \bullet$ & $\bullet$ & $\begin{array}{l}\text { Faecal analysis } \\
\text { or necroscopy }\end{array}$ & 600 & 48 & $8 \%$ \\
\hline \multicolumn{11}{|l|}{ Haemoparasite } \\
\hline $\begin{array}{l}\text { leucoctoyzoon } \\
\text { simond }\end{array}$ & - & $\bullet$ & $\bullet$ & $\bullet \bullet$ & $\bullet \bullet$ & $\bullet$ & $\begin{array}{c}\text { Blood smear } \\
\text { method }\end{array}$ & 600 & 78 & $13 \%$ \\
\hline $\begin{array}{l}\text { Plasmodium } \\
\text { juxtanucleare }\end{array}$ & - & $\bullet$ & $\bullet \bullet$ & $\bullet \bullet$ & $\bullet \bullet$ & $\bullet$ & $\begin{array}{c}\text { Blood smear } \\
\text { method }\end{array}$ & 600 & 176 & $29.3 \%$ \\
\hline $\begin{array}{l}\text { Aegyptinella } \\
\text { pullorum }\end{array}$ & $\bullet$ & $\bullet$ & $\bullet$ & $\bullet$ & $\bullet$ & $\bullet$ & $\begin{array}{l}\text { Blood smear } \\
\text { method }\end{array}$ & 600 & 90 & $15 \%$ \\
\hline \multicolumn{11}{|l|}{ Ectoparasite } \\
\hline $\begin{array}{l}\text { Fowl tick Args } \\
\text { persicus }\end{array}$ & - & $\bullet$ & $\bullet$ & $\bullet$ & $\bullet$ & $\bullet$ & $\begin{array}{c}\text { Physical } \\
\text { observation }\end{array}$ & $\begin{array}{l}\text { Observation } \\
\text { made on } \\
\text { weekly } \\
\text { basis }\end{array}$ & 56 & \\
\hline $\begin{array}{l}\text { Mite } \\
\text { Dermanyssus } \\
\text { gallinae }\end{array}$ & $\bullet$ & $\bullet$ & $\bullet$ & $\bullet \bullet$ & $\bullet \bullet$ & $\bullet$ & $\begin{array}{c}\text { Physical } \\
\text { observation }\end{array}$ & $\begin{array}{l}\text { Observation } \\
\text { made on } \\
\text { weekly } \\
\text { basis }\end{array}$ & 31 & \\
\hline
\end{tabular}

Present $=\bullet$, Absent $=\bullet \bullet$. 
of $C$. anatis was $40 \%$. Capillarian species are thread like nematodea present in the upper area of gastrointestinal tract particularly in esophagous and crop but also found in small intestine (Greiner and Ritchie, 1994; Zucca, 2000) Capillarial species can cause infection in domestic birds where deep litter contains number of eggs in soil or litter (Permin and Hansen, 1998). Heterakis gallinarum is also a nematodal worm and its prevalence was $28.3 \%$. According to Goldova et al. (2006) pheasants and partridges were infected by hetarakis. Menezes et al. (2003) documented that $H$. gallinarum is responsible for chronic typhilitis and haemosiderosis. $H$. gallinarum is also capable of transferring protozoan Histomonas meleagridis to birds (Dimitrov D et al. 2015).

Some protozoan parasites have zoonotic potential, and their interaction with infected specimen can cause disease in humans (Slifko et al. 2000). The probability of transmission of zoonotic disease is influenced by so many factors, such as agent stability, population density, animal handling, virulence, route and latent period (Slifko et al. 2000; Marietto-Gonçalves et al. 2008). During present study, three protozoan parasitic species were detected and their prevalence was Eimeria maxima $20.1 \%$, Histomonas meleagridis $8 \%$, Giardia lamblia $5.3 \%$ and Eimaria is host specific (Table 2) and mainly found in Galliformes, Columbiformes and poultry (Greiner and Ritchie 1994). Giardia is present in motile trophozoite and cyst stage (Burr et al. 2012). Up to 50\% mortality is caused by giardia and it can also lead to poor plumage and can reduce growth (Greiner and Ritchie, 1994). Histomonas is mostly transmitted in embryonated eggs of the cecal nematode Heterakis gallinarum. H. meleagridis is a protozoan parasite which lives in caeca and liver and causes disease in turkeys however it is less fetal in chicken (Dimitrov D et al. 2015).

Three species of parasites viz. Leucoctoyzoon simond, Plasmodium juxtanucleare and Aegyptinella moshkovskii were recorded from blood samples and their prevalence was $13 \%, 29.3 \%$ and $15 \%$, respectively. Haemoparasite are responsible of avian malaria and acute anemia (Vander Heyden, 1996). Avian haemoparasites are pathogenic to their hosts and result in high mortalities, retardation of growth, reproductive failure, reduced productivity and have negative impacts on behavior (Sørci and Møller, 1997; Merilae et al. 1999; Merino et al. 2000; Cardona et al. 2002; Sol et al. 2003; Dunn et al. 2011).

Infections with Plasmodium have been identified in all avian orders except Struthioniformes, the Coliiformes and the Trogoniformes (Valkiūnas et al. 2005). The highest diversity of Plasmodium has been recorded form the Columbiformes, Galliformes, and Passeriformes (Valkiūnas et al. 2005; Martinsen et al. 2008). Leucocytozoon has been reported from many avian orders but only some species are pathogenic to their host. Susceptible groups of avian hosts consist of poultry, pigeons, raptors, waterfowl and ostriches (Bennett et al., 1993). Haemoprotozoa are mostly transmitted by blackflies (Atkinson and Riper, 1991). In domestic poultry, only two species of Leucocytozoo i.e. L. sabrazesi and L. caulleryi have been reported (Colley et al. 1971). Leucocytozoon simondi was also recorded during present study. L. simondi is a blood parasite that can cause mortality in domestic geese and ducks and is transmitted by vector black flea (Atkinson and Riper, 1991; Desser and Bennett, 1993). Haemoproteus geneus is equally distributed in birds in all continents except Antarctica because there is no vector for the transmission (Valkiūnas et al., 2005).

Dimitrov D et al. (2015) documented that ectoparasites play important role in transmission of diseases and result in great loss to poultry. The fowl tick Argas persicus was also observed during present study. The fowl tick has origination in central Asia (Buczek et al., 2006). Basically, it was an old world parasite but it also exists in new world along with other species viz. Argas miniatus, A. radiates and A. sanchezi. In birds, A. persicus reduces growth and egg yield, also causes weakness and anemia that may lead to death (Khan et al., 2001). Furthermore, in chickens it causes paralysis. One species of chicken mite Dermanyssus gallinae was also observed during present investigation. D. gallinae is continuous blood feeder of chicken, pigeon, turkey and many other avian species. During day time, they live in crevices near host nest, leaving these crevices at night to feed blood of birds. Heavy infection of this mite can decrease egg production in poultry. It also causes anemia, and act as host for secondary infection.

Table 2. Parasites, their prediction sites, morphology, life cycle, clinical diagnosis and control measures.

\begin{tabular}{|c|c|c|c|c|c|}
\hline Parasites & Prediction site & Morphology & Life cycle & Clinical diagnosis & Control measures \\
\hline \multicolumn{6}{|c|}{ Nematodes (Round worm) } \\
\hline Syngamus trachea & Lungs and trachea & $\begin{array}{l}\text { Worms are } \\
\text { medium sized } \\
\text { and red in colour. } \\
\text { Females are } \\
\text { greater than male } \\
\text { measuring } 5 \text { to } \\
20 \mathrm{~mm} \text {, and male } \\
\text { is } 2 \text { to } 6 \mathrm{~mm} \text { and } \\
\text { egg size is } 70 \text { to } \\
100 \text { um }\end{array}$ & Direct or indirect & $\begin{array}{l}\text { Coughing, } \\
\text { sneezing and } \\
\text { respiratory } \\
\text { disorder. Death } \\
\text { occurs when } \\
\text { mucus block the } \\
\text { trachea. }\end{array}$ & $\begin{array}{l}\text { Keep the bird's } \\
\text { bedding as dry } \\
\text { as possible and } \\
\text { frequently change } \\
\text { it. Broad spectrum } \\
\text { anthelmintics } \\
\text { are used for } \\
\text { treatment. }\end{array}$ \\
\hline
\end{tabular}


Table 2. Continued..

\begin{tabular}{|c|c|c|c|c|c|}
\hline Parasites & Prediction site & Morphology & Life cycle & Clinical diagnosis & Control measures \\
\hline Capillaria annulata & $\begin{array}{l}\text { Mucosa of crop } \\
\text { and Esophagous }\end{array}$ & $\begin{array}{l}\text { Males are } 15 \text { to } 25 \\
\text { mm, females are } \\
37 \text { to } 80 \text { mm,and } \\
\text { eggs are } \sim 30 x 70 \\
\text { um }\end{array}$ & Direct or indirect & $\begin{array}{l}\text { Seriously harm } \\
\text { the lining of crop } \\
\text { and oesophagus. }\end{array}$ & $\begin{array}{l}\text { Restrict their } \\
\text { access to humid } \\
\text { area. Strict } \\
\text { hygiene of feeder } \\
\text { and drinker. } \\
\text { Tablets and } \\
\text { injections are } \\
\text { used for single } \\
\text { animal treatment } \\
\text { but for flock } \\
\text { anthelmintics are } \\
\text { used. }\end{array}$ \\
\hline Capillaria anatis & Cecum & $\begin{array}{l}\text { Males are } 15 \text { to } 25 \\
\text { mm, females are } \\
37 \text { to } 80 \mathrm{~mm} \text {,and } \\
\text { eggs are } \sim 30 \times 70 \\
\text { micrometer }\end{array}$ & Direct or indirect & Diarrhoea & $\begin{array}{l}\text { Anthelmintics are } \\
\text { used. }\end{array}$ \\
\hline Ascardia galli & Small intestine & $\begin{array}{l}\text { Worms are } \\
\text { semitransparent, } \\
\text { female length is } \\
72 \text { to } 160 \mathrm{~mm} \text {, and } \\
\text { male length is } 51 \\
\text { to } 61 \mathrm{~mm} \text {. eggs are } \\
72 \text { to } 93 \mathrm{um} \text {. }\end{array}$ & Direct & $\begin{array}{l}\text { Enteritis, loss } \\
\text { of appetite, } \\
\text { unthriftiness, } \\
\text { pale combs and } \\
\text { wattles, droopy } \\
\text { wings }\end{array}$ & $\begin{array}{l}\text { Pasture rotation, } \\
\text { Avoid to } \\
\text { moisture content, } \\
\text { anthelmintics are } \\
\text { used. }\end{array}$ \\
\hline $\begin{array}{l}\text { Heterakis } \\
\text { gallinarum }\end{array}$ & Caeca & $\begin{array}{l}\text { Male is } 7 \text { to } 13 \\
\mathrm{~mm} \text { female is } 10 \\
\text { to } 15 \mathrm{~mm} \text { long, } \\
\text { eggs are ovoid, } \\
\text { about } 45 \times 75 \mathrm{um} .\end{array}$ & Direct & $\begin{array}{l}\text { Nodules and small } \\
\text { bleeding in cecal } \\
\text { wall. Causative } \\
\text { agent for black } \\
\text { head disease. }\end{array}$ & $\begin{array}{l}\text { Anthelmintics are } \\
\text { used. }\end{array}$ \\
\hline Allodapa suctoria & Caeca & $\begin{array}{l}\text { Male is } 7 \text { to } 10 \\
\mathrm{~mm} \text {, female is } 9 \text { to } \\
18 \mathrm{~mm} \text { long and } \\
\text { egg size is } 52 \text { to } \\
64 \mathrm{um} \text {. }\end{array}$ & Indirect & Vomiting, nausea & $\begin{array}{l}\text { Control } \\
\text { intermediate host. }\end{array}$ \\
\hline \multicolumn{6}{|c|}{ Cestode (Tape worm) } \\
\hline $\begin{array}{l}\text { Raillietina } \\
\text { echinobothrida }\end{array}$ & Small intestine & $\begin{array}{l}10 \text { to } 25 \mathrm{~cm} \text {. size } \\
\text { of egg is } 74 \text { to } 93 \\
\text { um. }\end{array}$ & Indirect & $\begin{array}{l}\text { Reduce growth, } \\
\text { abdominal } \\
\text { disturbance }\end{array}$ & $\begin{array}{l}\text { Control } \\
\text { intermediate host. }\end{array}$ \\
\hline \multicolumn{6}{|c|}{ Trematodes (flukes) } \\
\hline $\begin{array}{l}\text { Prosthogonimus } \\
\text { ovatus }\end{array}$ & Cloaca and rectum & $\begin{array}{l}8 \text { to } 9 \mathrm{~mm} \text { and egg } \\
\text { is } 22 \text { to } 24 \mathrm{um}\end{array}$ & Indirect & $\begin{array}{l}\text { Milky discharge } \\
\text { from cloaca, lay } \\
\text { soft shell egg. }\end{array}$ & $\begin{array}{l}\text { Control of } \\
\text { secondary host. }\end{array}$ \\
\hline $\begin{array}{l}\text { Prosthogonimus } \\
\text { macrorchis }\end{array}$ & Intestine & $\begin{array}{l}7 \text { to } 9 \mathrm{~mm} \text { and egg } \\
\text { is } 20 \mathrm{um}\end{array}$ & Indirect & $\begin{array}{l}\text { Reduce growth, } \\
\text { thriftiness, } \\
\text { abdominal } \\
\text { discomfort. }\end{array}$ & $\begin{array}{l}\text { Sanitary practices, } \\
\text { avoid from } \\
\text { moisture area }\end{array}$ \\
\hline \multicolumn{6}{|c|}{ Protozoa (single cell) } \\
\hline Giardia lamblia & Intestinal tract & $\begin{array}{l}11 \text { to } 14 \mu \mathrm{m} \text { in } \\
\text { length and } 7 \text { to } \\
10 \mu \mathrm{m} \text { in width. } \\
\text { Two forms } \\
\text { trophozoite and } \\
\text { cyst: trophozoite }\end{array}$ & Direct. & $\begin{array}{l}\text { Weight loss, } \\
\text { Diarrhoea is } \\
\text { foul smelling, } \\
\text { scratching and } \\
\text { preening. }\end{array}$ & $\begin{array}{l}\text { Keep drinking } \\
\text { bottle clean.Use } \\
\text { cool boiled water. } \\
\text { Metronidazole is } \\
\text { used for common } \\
\text { treatment. }\end{array}$ \\
\hline
\end{tabular}


Table 2. Continued...

\begin{tabular}{|c|c|c|c|c|c|}
\hline Parasites & Prediction site & Morphology & Life cycle & Clinical diagnosis & Control measures \\
\hline Eimeria maxima & Small intestine & $\begin{array}{l}\text { Three } \\
\text { developmental } \\
\text { stages: schizonts, } \\
\text { gamonts and } \\
\text { oocysts. }\end{array}$ & Direct & $\begin{array}{l}\text { Cause catarrhalic } \\
\text { or haemorrhagic } \\
\text { enteritis, bloody } \\
\text { diarrhoea, }\end{array}$ & $\begin{array}{l}\text { Continuous } \\
\text { medication is } \\
\text { given in food } \\
\text { and and water. } \\
\text { sulfonamides } \\
\text { drug is most } \\
\text { common }\end{array}$ \\
\hline $\begin{array}{l}\text { Histomonas } \\
\text { meleagridis }\end{array}$ & Caeca and liver & $\begin{array}{l}\text { It has two forms: } \\
\text { a tissue-dwelling } \\
\text { (amoebic) form } \\
\text { and a caecal } \\
\text { lumen (has single } \\
\text { flagellum) form }\end{array}$ & Direct & $\begin{array}{l}\text { Infection occur } \\
\text { only when they } \\
\text { penetrate from } \\
\text { blood streams to } \\
\text { liver. }\end{array}$ & $\begin{array}{l}\text { Dimetridazole } \\
\text { is very effective } \\
\text { for treating } \\
\text { histomonosis. }\end{array}$ \\
\hline \multicolumn{6}{|l|}{ Blood parasites: } \\
\hline $\begin{array}{l}\text { Leucocyzoon } \mathrm{n} \\
\text { simond }\end{array}$ & $\begin{array}{l}\text { Leucocyte and } \\
\text { erythrocyte }\end{array}$ & $\begin{array}{l}\text { Oval in shape. } \\
\text { Mature } \\
\text { gametocyte } \\
\text { is } 14-22 \text { um. } \\
\text { gametocyte } \\
\text { is elongated } \\
\text { when found } \\
\text { in leukocytes } \\
\text { and round } \\
\text { when found in } \\
\text { erythrocytes. }\end{array}$ & Indirect & $\begin{array}{l}\text { The animals are } \\
\text { listless, anorectic, } \\
\text { anaemic and } \\
\text { have a laboured } \\
\text { breathing. CNS } \\
\text { symptoms. }\end{array}$ & $\begin{array}{l}\text { Treatment mostly } \\
\text { is not effective } \\
\text { and medication } \\
\text { is used in } \\
\text { combination form } \\
\text { pyrimethamine } \\
(1 \mathrm{ppm}) \text { nd } \\
\text { sulfadimethoxine } \\
(10 \mathrm{ppm}) \text { in the } \\
\text { feed }\end{array}$ \\
\hline $\begin{array}{l}\text { Plasmodium } \\
\text { juxtanucleare }\end{array}$ & Erythrocyte & $\begin{array}{l}\text { Round oval or } \\
\text { irregular in } \\
\text { shape mature } \\
\text { gametocyte is } \\
15.5 \text { um }\end{array}$ & Indirect & $\begin{array}{l}\text { Anaemia, diarrhoea } \\
\text { and weight loss } \\
\text { that may lead to } \\
\text { death. }\end{array}$ & $\begin{array}{l}\text { Treatment is } \\
\text { difficult in birds. } \\
\text { Because duration } \\
\text { of disease is 2-3 } \\
\text { days. }\end{array}$ \\
\hline $\begin{array}{l}\text { Aegyptinella } \\
\text { pullorum }\end{array}$ & Erythrocyte & $\begin{array}{l}\text { Small } 5 \text { to } 10 \mathrm{um} \text {, } \\
\text { round to oval } \\
\text { bodies. }\end{array}$ & Indirect & $\begin{array}{l}\text { Ruffled feather } \\
\text { birds may become } \\
\text { anorectic, droopy } \\
\text { and may suffer } \\
\text { from diarrhoea }\end{array}$ & $\begin{array}{l}\text { Duration is very } \\
\text { small. biosecurity } \\
\text { measures should } \\
\text { be taken to reduce } \\
\text { the introduction }\end{array}$ \\
\hline \multicolumn{6}{|l|}{ Ectoparasites: } \\
\hline $\begin{array}{l}\text { Fowl tick: Args } \\
\text { persicus }\end{array}$ & Skin & $\begin{array}{l}\text { Soft bodied tick } \\
\text { and the size of } \\
\text { female is } 10 \times 6 \\
\mathrm{~mm}\end{array}$ & Direct & $\begin{array}{l}\text { Anaemia, weight } \\
\text { loss, depression, } \\
\text { toxaemia, and } \\
\text { paralysis }\end{array}$ & $\begin{array}{l}\text { Houses should } \\
\text { be cleaned,walls, } \\
\text { ceilings, cracks, } \\
\text { and crevices } \\
\text { should be highly } \\
\text { sprayed with } \\
\text { carbaryl or } \\
\text { coumaphos }\end{array}$ \\
\hline $\begin{array}{l}\text { Mite: } \\
\text { Dermanyssus } \\
\text { gallinae }\end{array}$ & Skin & $\begin{array}{l}\text { The adult female } \\
\text { mites size is } 1 \\
\text { mm in length. The } \\
\text { colour may be } \\
\text { grey to deep red }\end{array}$ & Direct & $\begin{array}{l}\text { Reduction in } \\
\text { egg production, } \\
\text { anaemia and } \\
\text { itching effect } \\
\text { may change bird } \\
\text { behaviour. }\end{array}$ & $\begin{array}{l}\text { Cracks and } \\
\text { crevices should } \\
\text { be filled in-house } \\
\text { should be clean } \\
\text { and spray should } \\
\text { be used. }\end{array}$ \\
\hline
\end{tabular}

\section{Conclusions and Recommendation}

During present investigation, two species of ectoparasites and 17 species of endoparasites; three from blood and 14 from fecal samples were identified. In our recommendation, proper medication and sanitation of the birds houses and cages is recommended to avoid parasites.

\section{References}

ATKINSON, C.T., THOMAS, N.J. and HUNTER, D.B., 2009.Parasitic Diseases of Wild Birds. Hoboken, NJ: John Wiley \& Sons.

ADRIANO, E.A. and CORDEIRO, N.S., 2001. Prevalence and intensity of Haemoproteus columbae in three species of wild doves from Brazil. Memorias do Instituto Oswaldo Cruz, vol. 96, no. 2, pp. 175-178. PMid:11285493. 
AGUIRRE, A., MENA, A. and BARNETT, L., 1986. Epizootiological consideration of Haemoproteus infection of pigeons. Brazilian Journal of Poultry Science, vol. 30, pp. 275-281.

ATKINSON, C.T. and RIPER, V.C., 1991. Pathogenicity and epizootiology of avian haematozoa Plasmodium, Leucocytozoon and Haemoproteus. In: J.E. LOYE and M. ZUK. Bird-parasite interactions: ecology, evolution, and behaviour. Oxford: Oxford University Press, pp. 19-48.

BAGUST, T.J., 1994. Improving health for poultry production in Asia: A development perspective. Avian Pathology, vol. 23, no. 3, pp. 395-404. PMid:18671108.

BENNETT, G.F., PEIRCE, M.A. and ASHFORD, R.W., 1993. Avian haematozoa: mortality and pathogenicity. Journal of Natural History, vol. 27, pp. 993-1001.

BUCZEK, A., BARTOSIK, K., OLSZEWSKI, T., STĘPPIENŃ, K., KUBRAK, T. and SAŁATA, M. 2006. Host specificity of ticks (Acari: Ixodidae). In: A. BUCZEK and C. BŁASZAK. Arthropods: Epidemiological Importance. Lublin: Koliber. pp. 37-54.

BURR, H.N., PALUCH, L.R., ROBLE, G.S. and LIPMAN, N.S., 2012. Parasitic Diseases. In M.A.SUCKOW, K.A. STEVENS, R.P. WILSON. The Laboratory Rabbit, Guinea Pig, Hamster, and Other Rodents. Waltham: Academic Press, pp. 839-866.

CARDONA, C.J., IHEJIRIKA, A. and MCCLELLAN, L., 2002. Haemoproteus lophortyx infection in Bobwhite quail. Avian Diseases, vol. 46, no. 1, pp. 249-255. PMid:11922345.

COLLEY, F.C., RAHMAN, M.A. and OMAR, I.B., 1971. Blood parasites of domestic fowl in Malaysia. The Southeast Asian Journal of Tropical Medicine and Public Health, vol. 2, no. 1, pp. 84-85. PMid:5165246

COOPER, J.E., 2005. Birds of prey: Health and Disease. 3rd eds. Oxford, UK: Blackwell Publishing, $120 \mathrm{p}$.

DESSER, S.S. and BENNETT, G.F., 1993.The genera Leucocytozoon, Haemoproteus and Hepatocystis. In: J.P. KREIER, ed. Parasitic protozoa. London: Academic Press, vol. 4, pp. 273-305.

DIMITROV, D., PALINAUSKAS, V., IEZHOVA, T.A., BERNOTIENĖ, R., ILGŪNAS, M., BUKAUSKAITĖ, D. and VALKIŪNAS, G., 2015. Plasmodium spp.: an experimental study on vertebrate host susceptibility to avian malaria. Experimental Parasitology, vol. 148, pp. 1-16. PMid:25450775.

DRANZOA, C., OCAIDO, M. and KATETE, P., 1999. The ecto-gastrointestinal and haemo-parasites of live pigeons (Columba livia) in Kampala, Uganda. Avian Pathology, vol. 28, no. 2, pp. 119-124. PMid:26911497.

DUNN, J.C., COLE, E.F. and QUINN, J.L., 2011. Personality and parasites: sex-dependent associations between avian malaria infection and multiple behavioral traits. Behavioral Ecology and Sociobiology, vol. 65, pp. 1459-1471

FATIHU, M.Y., OGBOGU, V. C., NJOKU, C.O., and SAROR, D.I., 1991. Comparative studies of gastrointestinal helminthes of poultry in Zaria, Nigeria. Revue D'Elelevage et de Medecin Veterinaire des pays Troicaux, vol. 44, pp. 175-177.

GOLDOVA, M., CSIZSMAROVA, G., LETKOVA, V., KOCIS, J. and KOLODZIEYSKI, L., 1993. Duration of endogenous developmental phase of Eimeria colchici and Eimeria duodenalis in pheasants (Phasianus colchicus). Veterinarÿstvi, vol. 43, pp. 286-287.

GOLDOVÁ, M., PALUŠ, V., LETKOVÁ, V., KOČIŠOVÁ, A., ČURLÍK, J. and MOJŽIŠOVÁ, J., 2006. Parasitoses in pheasants (Phasianus colchicus) in confined systems. Veterinarski Arhiv, vol. 76, pp. 83-89.
GREINER, E., 1997. Parasitology. In: R.B. ALTMANN, S.L. CLUBB, G. DORRESTEIN and K. QUESENBERRY, eds. Avian Me dicine and Surgery. Philadelphia: W.B.Saunders Company, pp. 332-349.

GREINER, E. and RITCHIE, B., 1994. Parasites. In: B. W. RITCHIE, G. J. HARRISON and L. R. HARRISON. Avian Medicine, Principles and Application. Lake Worth: Wingers Publishing Company, pp. 1006-1029.

GYLSTORFF, I. and GRIMM, F., 1998. Vogelkrankheiten. 2nd ed. Verlag Eugen Ulmer.

KHAN, M.N., KHAN, L.A., MAHMOOD, S. and QUDOOS, A., 2001. Argas persicus infestation: prevalence and economic significance in poultry. Pakistan Journal of Agricultural Sciences, vol. 38, pp. 32-34.

KRYSTIANIAK, S., KONTECKA, H., NOWACZEWSKI, A. and ROSINSKI, A., 2007. Laying characteristics of one and two-year old pheasants Phasianus colchicus, L. Folia Biologica, vol. 55, no. 1-2, pp. 1-2. PMid:17687936.

MARIETTO-GONÇALVES, G.A., FERNANDES, T.M., SILVA, R.J., LOPES, R.S. and ANDREATTI FILHO, R.L., 2008. Intestinal protozoan parasites with zoonotic potential in birds. Parasitology Research, vol. 103, no. 5, pp. 1237-1240. PMid:18663476.

MARTINSEN, E.S., PERKINS, S.L. and SCHALL, J.J., 2008. A threegenome phylogeny of malaria parasites (Plasmodium and closely related genera): evolution of life-history traits and host switches. Molecular Phylogenetics and Evolution, vol. 47, no. 1, pp. 261-273. PMid:18248741.

MENEZES, R.C., TORTELLY, R., GOMES, D.C. and PINTO, R.M., 2003. Nodular typhlitis associated with the nematodes Heterakis gallinarum and Heterakis isolonche in pheasants: frequency and pathology with evidence of neoplasia. Memorias do Instituto Oswaldo Cruz, vol. 98, no. 8, pp. 1011-1016. PMid:15049081.

MERILAE, J., SHELDON, B.C. and LINDSTROEM, K., 1999. Plumage brightness in relation to haematozoan infections in the greenfinch Carduelis chloris: bright males are a good bet. Ecoscience, vol. 6, pp. 12-18.

MERINO, S., MORENO, J., SANZ, J.J. and ARRIERO, E., 2000. Are avian blood parasites pathogenic in the wild.A medication experiment in blue tits (Parus caeruleus). Proceedings of the Royal Society of London. Series B, Biological Sciences, vol. 267, no. 1461, pp. 2507-2510. PMid:11197126.

PANDEY, V.S., DEMEY, F. and VERHULST, A., 1992. Parasitic Diseases: A neglected problem in village poultry in sub-saharan Africa. Antwerpen: Institute of Tropical Medicine, pp.136-141.

PERMIN, A., MAGWISHA, H., KASSUKU, A.A., NANSEN, P., BISGAARD, M., FRANDSEN, F. and GIBBONS, L., 1997 A crossesectional study of helminth in rural scavenging poultry in Tanzania in relations to season and climate. Journal of Helminthology. http://dx.doi. org/10.1017/S0022149X00015972. PMid:9271471.

PERMIN, A. and HANSEN, J.W., 1998. Epidemiology, Diagnosis and Control of Poultry Parasites. An FAO Handbook. Rome, Italy Food Agric Organ UN. 22-23.

SLIFKO, T.R., SMITH, H.V. and ROSE, J.B., 2000. Emerging parasite zoonoses associated with water and food. International Journal for Parasitology, vol.30, no. 12-13, pp. 1379-1393. PMid:11113263.

SOL, D., JOVANI, R. and TORRES, J., 2003. Parasite mediated mortality and host immune response explain age-related differences in blood parasitism in birds. Oecologia, vol. 135, no. 4, pp. 542547. PMid:16228253.

SOL, D. and LEFEBVRE, L., 2000. Behavioural flexibility predicts invasion success in birds introduced to New Zealand. Oikos, vol. 90, no. 3, pp. 599-605.

SØRCI, G. and MØLLER, A.P., 1997. Comparative evidence for a positive correlation between haematozoan prevalence and mortality in waterfowl. Journal of Evolutionary Biology, vol. 10, pp. 731-741. 
VALKIŪNAS, G., ANWAR, A.M., ATKINSON, C.T., GREINER, E.C., PAPERNA, I. and PEIRCE, M.A., 2005. What distinguishes malaria parasites from other pigmented haemosporidians. Trends in Parasitology, vol. 21, no. 8, pp. 357-358. PMid:15967726.

VANDER HEYDEN, N., 1996. Hameoparasites. In: W. J. ROSSKOPF JUNIOR and R. W. WOERPEL. Diseases of cage and aviary birds. 3rd ed. Philadelphia, PA: Lea \& Febiger, pp. 627-629.
VAN HEMERT, C., MEIXELL, B.W., SMITH, M.M. and HANDEL, C.M., 2019. Prevalence and diversity of avian blood parasites in a resident northern passerine. Parasites $\mathcal{E}^{\prime}$ Vectors, vol. 12, no. 1, pp. 292. PMid:31182151.

ZUCCA, P., 2000. Infectious diseases. In: J. SAMOUR, ed. Avian medicine. London, Tokyo: Mosby, pp. 219-244. 